\title{
Improvement Separation Layer of Disconnected Piled Raft Foundations using Geogrid and Geocell Layers
}

\author{
Ayat I. Khali1 ${ }^{1, \mathrm{a}}{ }^{*}$, Mahmood R. Mahmood ${ }^{2, \mathrm{~b}}$, and Husam H. Baker ${ }^{3, \mathrm{c}}$ \\ ${ }^{1}$ Civil Engineering Department. University of Technology-Iraq, Baghdad, Iraq. \\ aayatflower1996@gmail.com, bmahmoudal_qaissy@yahoo.com, chusamhb65@yahoo.com
}

\begin{abstract}
To control the problems of high stresses and applied moments in the piled raft foundations disconnected piled were used and the piles considered as reinforcement to the soil rather than as structural members, the gap (separation layer) between the piles and the raft can be filled with stabilized granular material which distributes the stresses below the raft and decreases the concentration stresses at the pile heads. Fifteen model tests were performed using three precast concrete pile models embedded within soft clayey soil of undrained shear strength $30 \mathrm{kPa}$. Flexi-Force sensors were used fixed on piles head and the surrounding soil to measure the sharing load transmitted to piles and the surrounding soil. Geogrid and geocell materials were used in different depths and in multilayers to reinforce the separation layer and increase its stiffness. The results show that when reinforcing the separation layer with geogrid at different depths, an increase in depth over the top of the piles reduced the bearing pressure. When used, geocell reinforcement significantly increases in load carrying capacity, and a significant reduction in footing settlement occurs.
\end{abstract}

Keywords: Piled raft; disconnected piled raft; separation layer; geogrid, geocell.

\section{Introduction}

In the presence of such geotechnical /structural factors, the raft and pile foundations can be combined productively to increasing the ultimate bearing capacity and decreasing settlements, as Burland et al. initially suggested [1]. In this regard, piled rafts (PRs) and disconnected piled rafts (DPRs) must be divided based on whether the piles are structurally attached to the raft or not. In piled raft system, the piles are connected to the raft and transfer the applied load to the deeper soil strata. These piles act as settlement reducers, which leads to significant bending moments and shear forces. to control the problem of lateral shear forces and bending moments in the piles and raft, Wong et al. [2] and Cao et al. [3] proposed disconnecting the piles from the raft and treating them as subsoil reinforcement rather than structural members. Furthermore, the gap between the raft and the unconnected piles could be filled with a structural fill layer.

Liang et al. [4] suggested that the sand-gravel mixture compacted into the layers between the raft and top of the piles plays a major role in mobilizing the load-transfer mechanism of the subsoil, as well as in modifying the pile load transmission. Since then, it has been described by many authors, Fioravante et al. [5] found that the stiffness and thickness of the interposed cushion layer governed this mechanism. They also showed that the unconnected piled rafts' efficacy could be lesser than that of the analog connected piled raft if the granular cushion layer is not sufficiently rigid due to the pile's carrying capacity not being fully mobilized. Eslami and Malekshah [6] showed that the average settlement reduces either from the decreasing in a thickness of gap or increasing the filling material's stiffness by conducted numerical elastoplastic analyses. They also showed that the depth of the maximum axial stress along the piles varied depending on the stiffness and the thickness of the interposed filling material. Sharma et al. [7] studied the modified type of foundation's behavior subjected to vertical load utilizing the Finite Element Method. They showed that using the cushion will adjust the piles' load-sharing ratios and subsoil and among the piles. 


\section{Materials, Equipment, and Test Setup}

Soil-Model Apparatus to study the disconnected piled-raft system's behavior under the static load, a new apparatus is manufactured as shown in Figure 1. The soil-model apparatus consists of the following: Steel container of $600 \mathrm{~mm}$ width, $600 \mathrm{~mm}$ length and $700 \mathrm{~mm}$ height, axial loading system (Loading Frame and Hydraulic Jack), and loading-deformation control equipment such as load cell, weight indicator, pressure sensors, reference beam, holders, dial gauges and Flexi-force sensors.

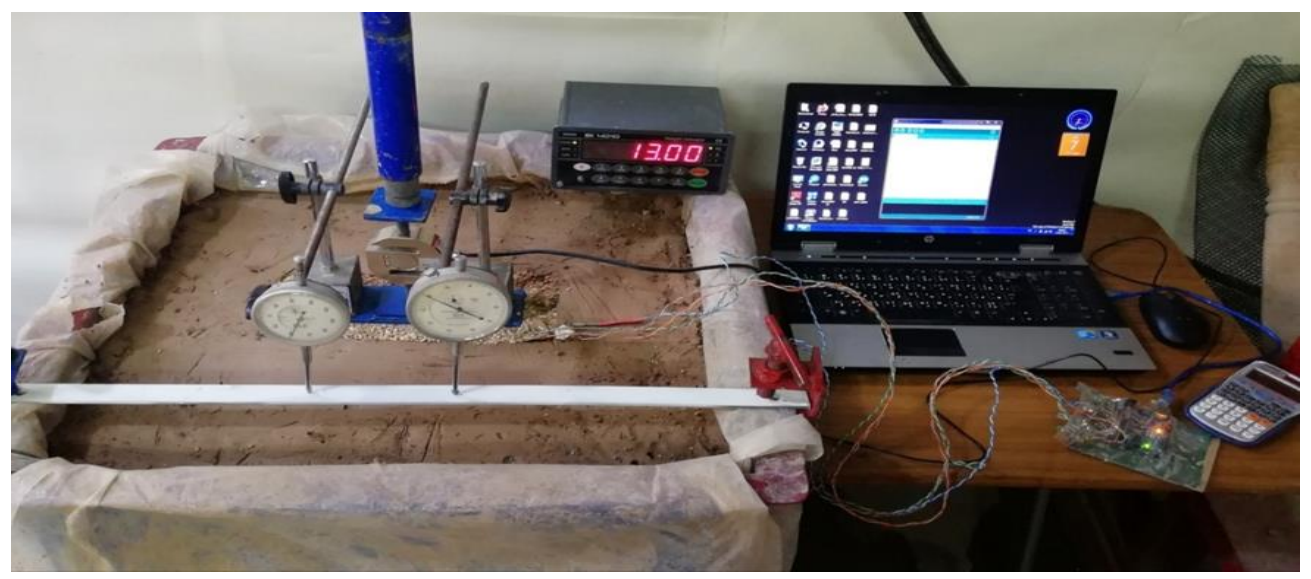

Figure 1. Soil model apparatus.

The soil used. The soil used in this study was cohesive soil. The summary of the physical properties of the soil tested can be shown in Table 1. According to the unified soil classification system (USCS), the soil is classified as clayey soil of low plasticity (CL). The grain size distribution of the soil used is shown in Figure 2. At the same time, the dry density and optimum moisture content are shown in Figure 4.

Cushion-Soil layer. Cushion-Soil layer is a coarse sandy soil used as a base material under the raft foundation and above the unconnected piles head. This soil's physical properties are shown in Table 1, while the grain size distribution and standard compaction curves are shown in Figures 3 and 5, respectively.

Table 1. Summary of physical soil properties for natural soil and cushion.

\begin{tabular}{|c|c|c|c|}
\hline \multirow[t]{2}{*}{ Test } & \multicolumn{2}{|c|}{ Property } & \multirow[t]{2}{*}{ Standard } \\
\hline & Natural Soil & $\begin{array}{l}\text { Cushion } \\
\text { Soil }\end{array}$ & \\
\hline Atterberg's limits (LL, PL and PI)(\%) & $43,23,20$ & - & ASTMD 4318[8] \\
\hline Specific gravity $\left(\mathrm{G}_{5}\right)$, & 2.7 & 2.65 & ASTMD 854[9] \\
\hline $\begin{array}{l}\text { Maximum dry density, }(\mathrm{kN} / \mathrm{m} 3) \\
\text { Optimum moisture content, }(\%)\end{array}$ & $\begin{array}{c}17.3 \\
20\end{array}$ & $\begin{array}{l}23.5 \\
11.5\end{array}$ & ASTMD 1557[10] \\
\hline $\begin{array}{l}\text { Maximum unit weight, } \gamma \mathrm{d}(\max ) \text {, } \\
\left(\mathrm{kN} / \mathrm{m}^{3}\right) \\
\text { Minimum unit weight, } \gamma \mathrm{d}(\mathrm{min}) \text {, } \\
\left(\mathrm{kN} / \mathrm{m}^{3}\right)\end{array}$ & - & $\begin{array}{l}17 \\
15\end{array}$ & ASTM D4253[11] \\
\hline $\begin{array}{l}\text { Particle size analysis: } \\
\mathrm{D}_{10},(\mathrm{~mm}) \\
\mathrm{D}_{30},(\mathrm{~mm}) \\
\mathrm{D}_{50},(\mathrm{~mm}) \\
\mathrm{D}_{60},(\mathrm{~mm}) \\
\text { Passing sieve }(0.075 \mathrm{~mm}),(\%) \\
\text { Classification }\end{array}$ & $\begin{array}{c}- \\
- \\
0.002 \\
0.05 \\
98 \\
\text { CL }\end{array}$ & $\begin{array}{c}0.7 \\
1.6 \\
2.3 \\
2.6 \\
0 \\
\text { SP }\end{array}$ & ASTMD 422[12] \\
\hline
\end{tabular}




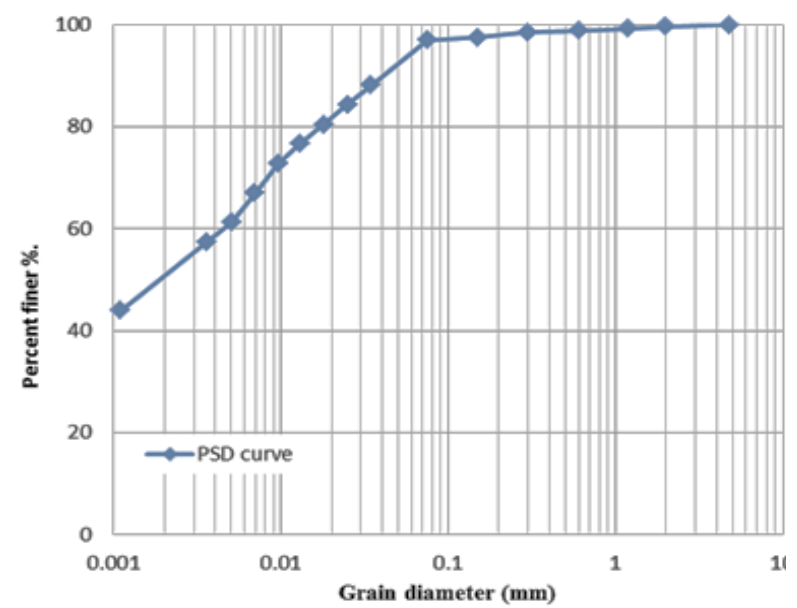

Figure 2. Particle size analysis for the soil used.

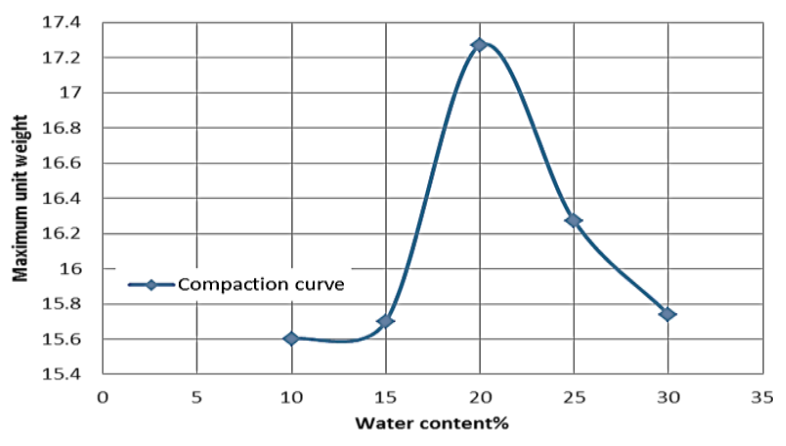

Figure 4. Compaction test for clay soil.

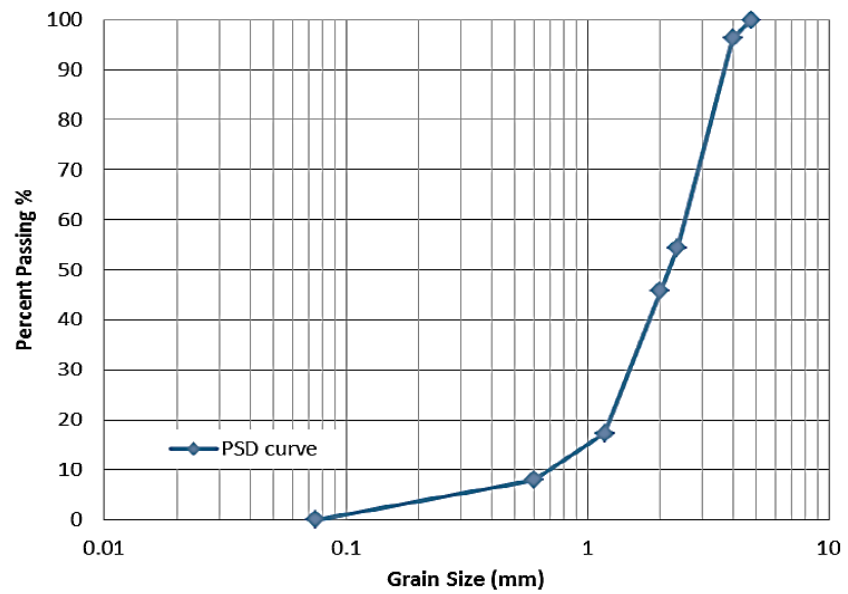

Figure 3. Particle size analysis for soil cushion soil.

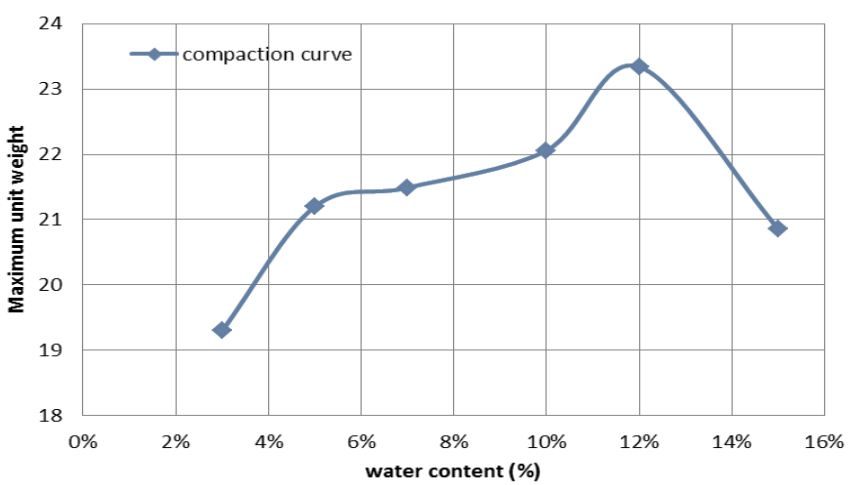

Figure 5. Compaction test for cushion soil.

Flexi-Force Sensors. It is a piezoresistive force sensor from Tekscan. The sensor is itself flexible as well as thin. While flexing, the resistance does not change. Only when pressure is applied to the circular region at the end of the sensor does the resistance change. It is used to investigate the shared load between piles and the surrounded soil from the total applied load. To calibrate the pressure sensors, the load is applied to the sensor with a value of $110 \%$ of the load test gradually. After that, allow the sensor to be stabilized, and then remove the load and repeat the process five times. More loading arrangements were devised to transfer the dead weight to the sensing area using the dead weight calibration system (Calibration of Tactile Pressure Sensor [13]). Figure 6 shows the distribution of Flexi-Force Sensors at the top of piles and at the surrounded soils.

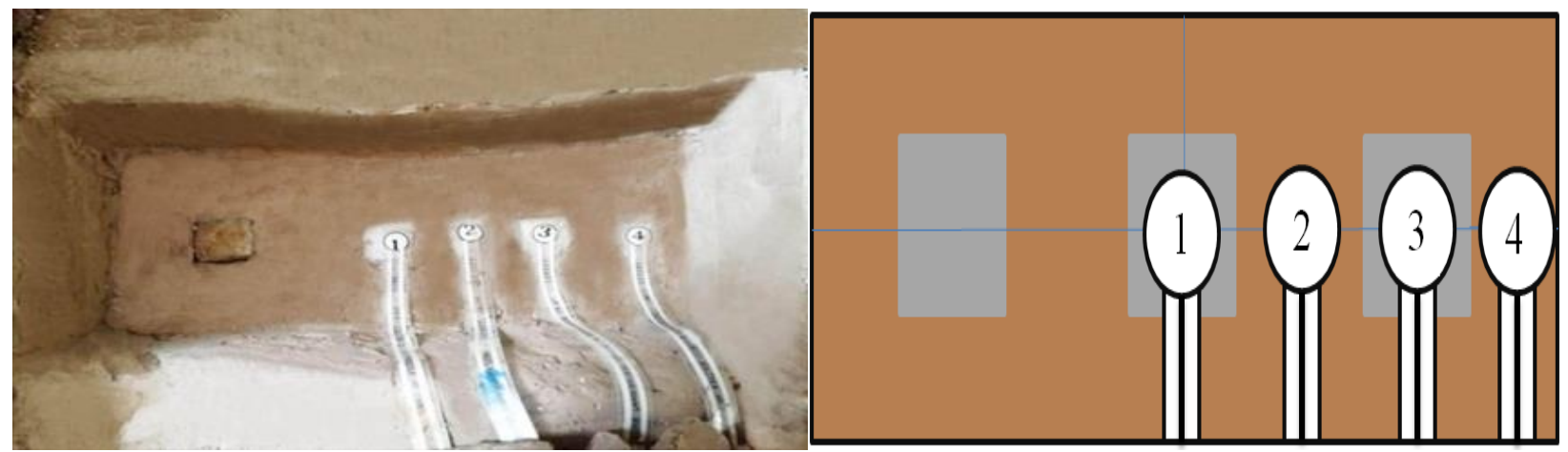

Figure 6. Fixed the sensors on top of piles and the surrounded soil.

Raft and Pile Models. The raft model was simulated by using a steel plate as a rigid raft of $7 \mathrm{~mm}$ thickness $70 \mathrm{~mm}$ width and $230 \mathrm{~mm}$ length and three reinforcement concrete pile models of $400 \mathrm{~mm}$ length and $25 \times 25 \mathrm{~mm}$ cross-section width. The reinforcement of each pile consists of four bars of 
$3 \mathrm{~mm}$ diameter and $380 \mathrm{~mm}$ in length. After 24 hours, the piles of concrete are cured for 28 days. The process of pile installation starts directly after the preparation of soil layers. The soil is cut by a special cutter to the desired depth, then the piles individually driven in the soil. The Balance tool is used to avoid pile inclination during the installation process, as shown in Figure 7.

Geogrid Layers. The geogrid layer shown in Figure 8 was used in all the tests. The properties of the Geo-grid material are summarized in Tables 2 and 3.

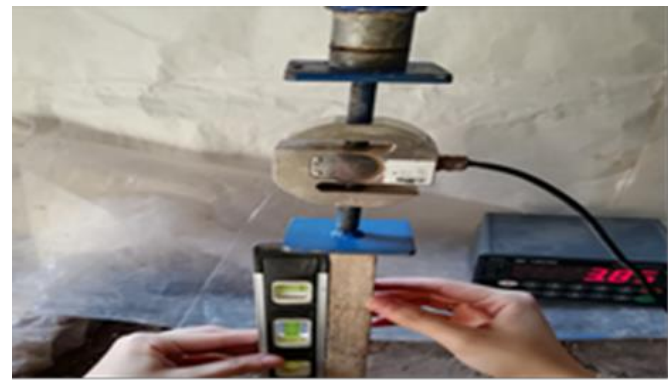

Figure 7. Installation of piles.

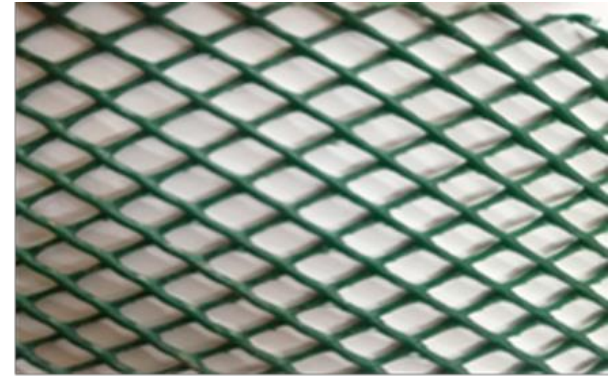

Figure 8. Geogrid layer.

Table 2: Mechanical and dimensional properties of geogrid material.

\begin{tabular}{|c|c|c|c|c|c|c|c|}
\hline Property & Test Method & Unit per Length & Value & Property & $\begin{array}{c}\text { Test } \\
\text { Method }\end{array}$ & Unit & Value \\
\hline Tensile strength at 2\% & ISO10319 & $\mathrm{kN} / \mathrm{m}$ & 4.3 & Aperture size & & $\mathrm{mm}$ & $6^{*} 6$ \\
\hline Tensile strength at 5\% & ISO10319 & $\mathrm{kN} / \mathrm{m}$ & 7.7 & Mass per unit area & ISO 9864 & $\mathrm{~g} / \mathrm{m}^{2}$ & 363 \\
\hline Peak tensile strength & ISO10319 & $\mathrm{kN} / \mathrm{m}$ & 13.5 & Roll width & & $\mathrm{m}$ & 1 \\
\hline Yield point Elongation & ISO10319 & $\mathrm{kN} / \mathrm{m}$ & 20.0 & Roll length & & $\mathrm{m}$ & 30 \\
\hline
\end{tabular}

*Determined following Saudi Arabian Standard Organization (SASO) Procedures.

Preparation of Geocell layer. The geocell mattress in Figure 9 was constructed at the highest part of the pile head and prepared by cutting the geo-grids to the desired width and height. Then set up the geo-grids in transverse and diagonal directions and connected by plastic strips at the joints (act as ATRA key) [14]. All the geocell layers are formulated only in the chevron pattern, as this gives the higher performance of improvement compared to the diamond pattern [15]. The height of the geocell equal to $0.9 \mathrm{~B}$, and the width is $2 \mathrm{~B}$ (i.e., approximately equal to the cushion layer's width and height). After forming the geocell layer, the geocell pockets were filled with granular cushion at specific relative density.
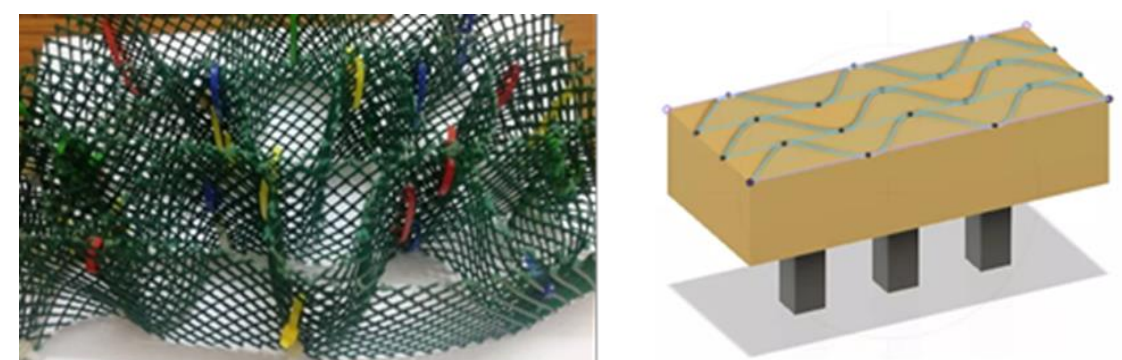

Figure 9. Top view of Geocell Formation inside the cushion layer.

Measurement of Applied Load. The application of load is according to the specification ASTM No.D1194-87[16] (Standard Test Method for Bearing Capacity of Soil for Static Load and Spread Footings). During the testing process, the load was placed centrally and vertically on a raft and applied by means of a hydraulic jack with an increment of not more than one-tenth of the estimated allowable bearing load from the theoretical approach. The load was measure and read accurately from:

1. Load cell: represent the total load applied to the system.

2. Flexi-Force Sensors: represent the load portion that reaches the pile and soil under the cushion layer. 
After the application of each load increment, maintain the cumulative load for a time interval of $15 \mathrm{~min}$ and measure the load. The settlement was recorded from two dial gauges after applying load with equal time intervals $(15 \mathrm{~min})$. The load increments were continued until the total settlement reached $10 \%$ of the raft width $(7 \mathrm{~mm})$.

\section{Discussion of Results}

A few criteria were used to define the foundation and piles' load failure, some of which are characterized by Fellenius [17]. In this study, for all model tests, Terzaghi's proposal, which described the load corresponding to the displacement of $10 \%$ of the width $\mathrm{f}$ footing (diameter of the pile), has been adopted to define the failure criteria raft and the disconnected piled raft foundation system.

Effect the thickness of the cushion layer. Eight model tests were carried out, four models using a cushion on clayey soil only (Cushion thickness of B, 0.5B, $0.25 \mathrm{~B}$, and direct on soil). Another four model tests using the same cushion thickness but rested on a group of three piles. Figure 10 shows the behavior of load settlement curves for an unconnected piled raft with different cushion thickness. The results show that the highest bearing pressure equal to $(1860 \mathrm{~N})$ for using a cushion layer of thickness $\mathrm{B}$ and $(1500 \mathrm{~N})$ for a raft on clay only without cushion. It is concluded that for a relatively thin layer of sand $(\mathrm{H}<\mathrm{B})$, the bearing pressure extended to the underlying soft clay subgrade, which provided lower resistance. Whereas, for the thick layers $(\mathrm{H}=\mathrm{B})$, the failure surface develops within the cushion layer, and the sand behavior dominates the layered responses to the bearing pressure Table 4 shows the ultimate bearing capacity for each case.

Table 4: Ultimate bearing capacity for disconnected piled raft without adding piles.

\begin{tabular}{|c|c|}
\hline The case & $\mathbf{Q u t t}_{\text {ult }}(\mathbf{N})$ \\
\hline Raft + Clay soil without cushion & 1500 \\
\hline Raft + clay +Cushion1B $(70 \mathrm{~mm})$ & 1860 \\
\hline Raft + clay + cushion0.5 $(35 \mathrm{~mm})$ & 1790 \\
\hline Raft + clay + cushion0.25 $(17.5 \mathrm{~mm})$ & 1650 \\
\hline
\end{tabular}

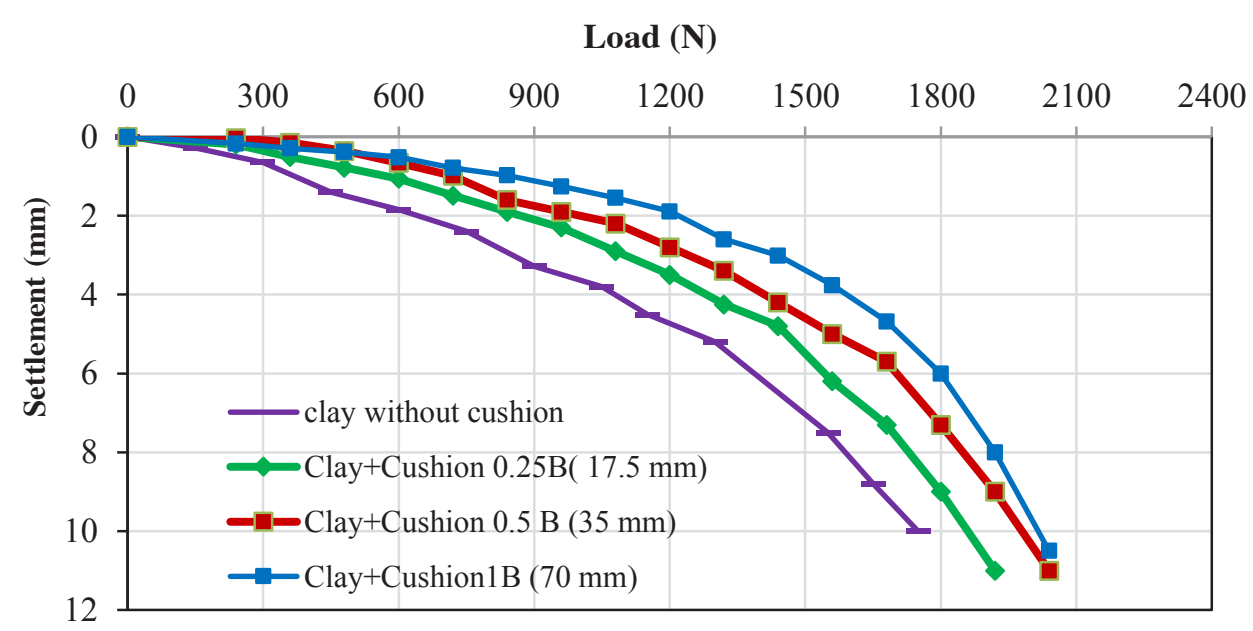

Figure 10. Effect of cushion thickness for disconnected piled raft without piles.

Figure 11 shows the load-settlement relationship of disconnected piled rafts for cushion resting on a group of three piles in. The piled rafts' curves show higher bearing than that of the reference tests (case 1) because of the pile being under the separation layer and had higher stiffness compared with clay soil. The load increased until it reached max value when the cushion zero's thickness (without adding cushion). Table 5 shows the disconnected piled raft's ultimate bearing capacity with adding pile group and optimization ratio. 
Table 5. Ultimate bearing capacity for a disconnected piled raft with adding piles

\begin{tabular}{|c|c|}
\hline The case & Qult $_{\text {(N) }}$ \\
\hline Cushion thickness of B $(70 \mathrm{~mm})+3$ piles & 2000 \\
\hline Cushion thickness of 0.5B (35 mm) 3 piles & 2780 \\
\hline Cushion thickness of 0.25B (12.5 mm) +3 piles & 3000 \\
\hline Raft on 3 piles (without cushion) & 3380 \\
\hline
\end{tabular}

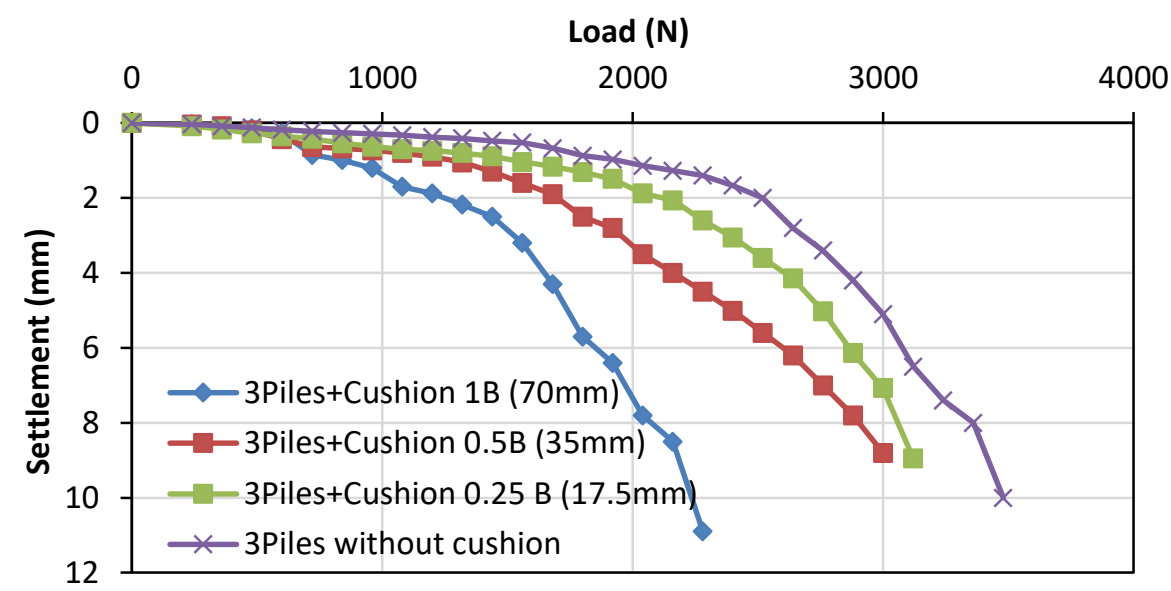

Figure 11. Effect of cushion thickness for disconnected piled raft with piles groups.

Sharing Load Between Piles and Clayey Soil from Total Applied Load. Figures 12 to 15 show the sharing of applied loads between piles and the surrounding soil from the total applied load in case of adding a cushion layer with different thicknesses. At low stress levels, a change in the separation layer's thickness negatively influences the pile portion. At a high-stress level, this effect is more reliable. During the early stage of loading, the share of the piles in the overall load applied is small and increases with the load level, and then the portion of piles begins to increase and ultimately becomes constant rapidly. An increase in the separation layer's thickness reduces the portion of the piles from the overall load, increasing the cushion thickening and increasing the load on the cushion, causing fewer force to be applied to the pile. The thickness $(\mathrm{H}<\mathrm{B})$ of the maximum part of the piles is reached.

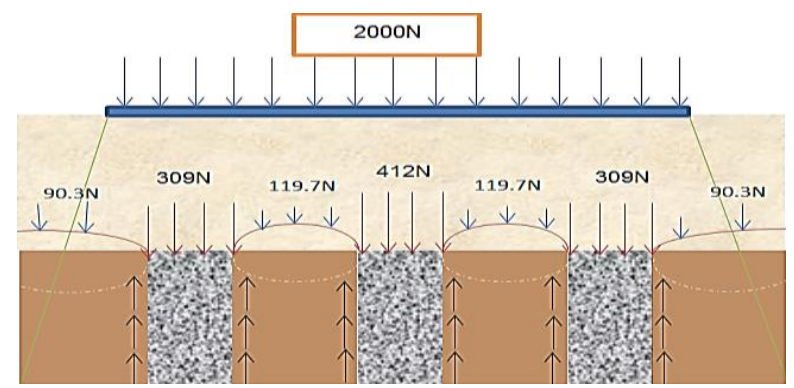

Figure 12. Sharing of load in cushion thickness $1 \mathrm{~B}$.

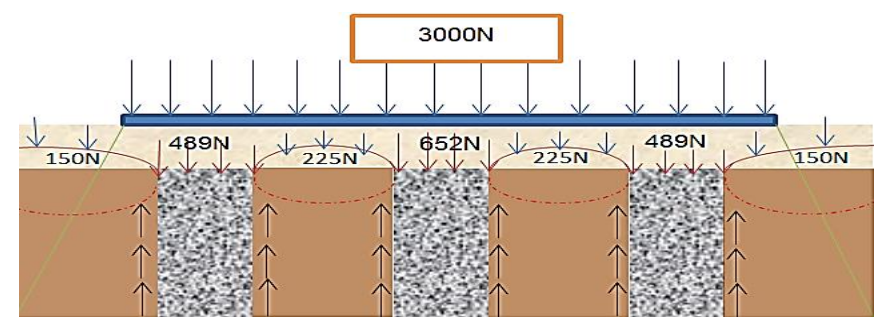

Figure 14.Sharing of load from total load cushion $0.25 \mathrm{~B}$.

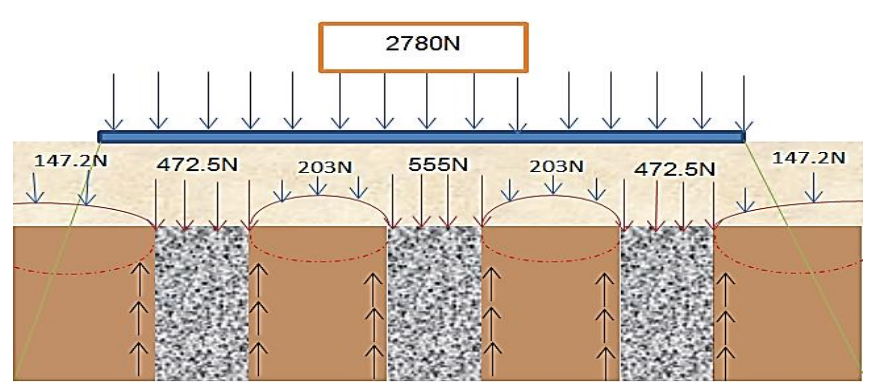

Figure 13. Sharing of load in cushion thickness $0.5 \mathrm{~B}$.

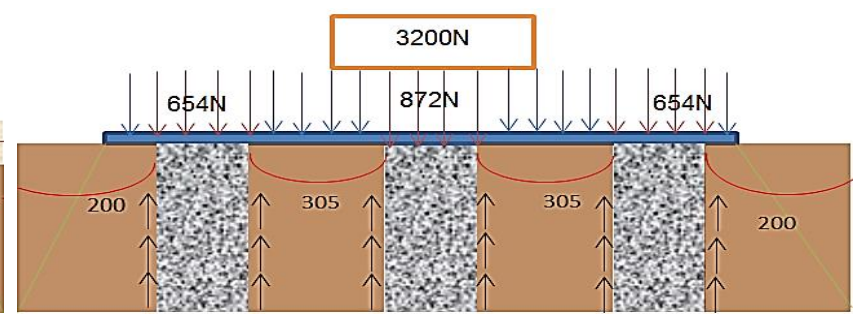

Figure 15. Sharing of load from total load without cushion. 
Effect of Geogrid Reinforcement. Several model tests were observed by reinforced the cushion layer by adding geogrid layers in different locations. The geogrid lies directly on piles, at a depth location of $0.25 \mathrm{~B}$, at a depth of $0.5 \mathrm{~B}$, and at depth B. Figure 16 shows the settlement various bearing load in different geogrid layers positions in the cushion resting on a group of three piles. Table 6 shows the ultimate bearing capacity for a disconnected piled raft using geogrid in different locations with piles groups. When the geogrid from the top of the piles increased, the loading pressure decreased. For geogrid directly located on the piles, which led the load transmitted directly into the batteries, the geogrid layer acts as a tension membrane, increases the force applied to the piles, and therefore increases the load pressure on the piles.

Table 6. Ultimate bearing capacity for a disconnected piled raft with using geogrid in different locations

\begin{tabular}{|c|c|}
\hline The case & Qutt (N) \\
\hline Clay+ 3 piles + Cushion 1B +geogrid at 70 mm & 2650 \\
\hline Clay+ +3 piles + Cushion 1B geogrid at 52 mm & 2380 \\
\hline Clay+3 piles + Cushion 1B +geogrid at 35mm & 2250 \\
\hline Clay+3 piles + Cushion 1B +geogrid at 17.5 mm & 2100 \\
\hline
\end{tabular}

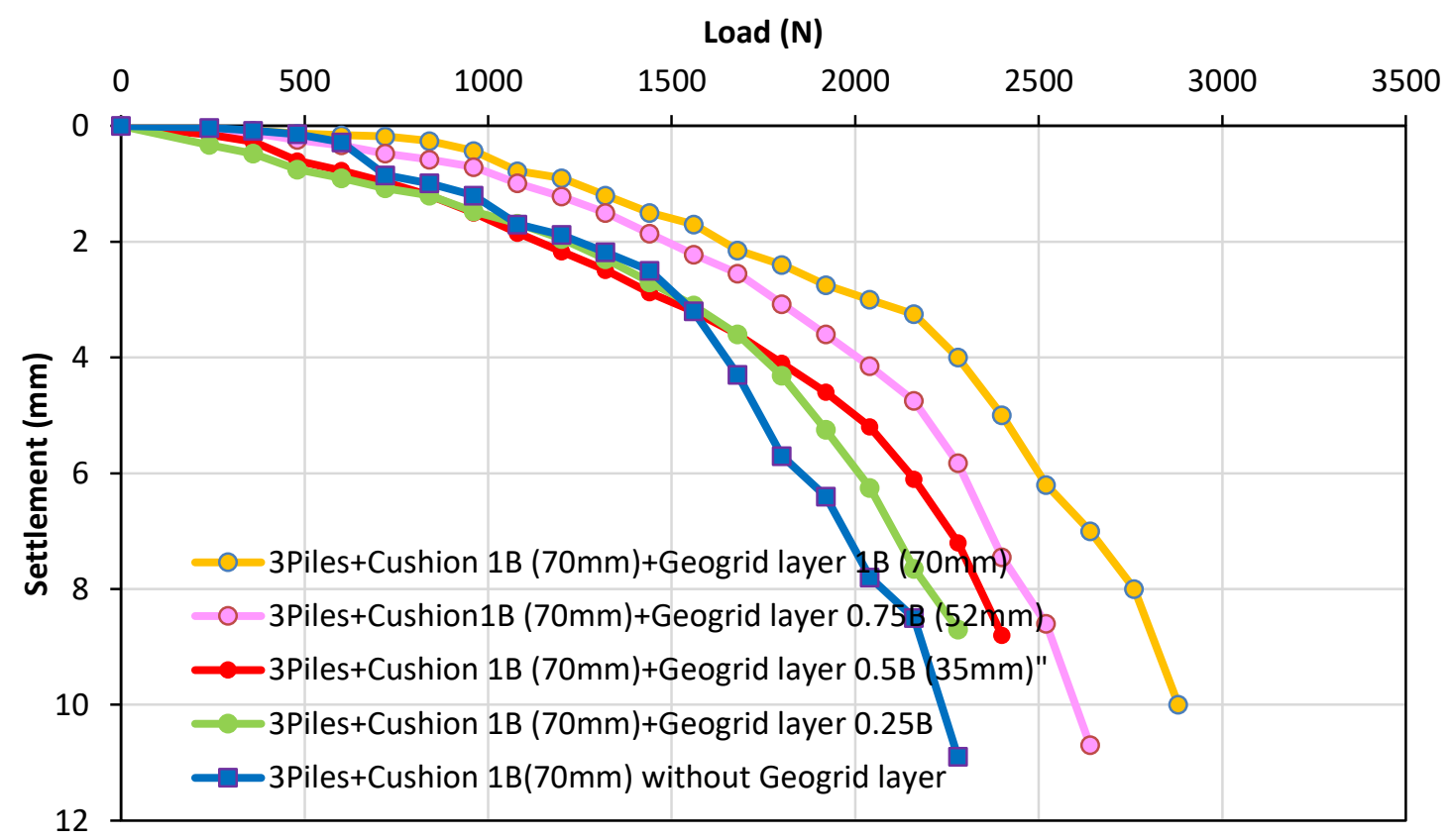

Figure 16. Effect of Geogrid layer in reinforcement cushion in different locations for a disconnected piled raft with piles groups.

Sharing Load of Geogrid Reinforcement on piles group from total applied load Figures 17 to 20 show the share of piles and soil the loads from the total applied load to add geogrid to reinforce the cushion layer at different locations. At low-stress levels, a change in geogrid location within the separation layer has little influence on the portion of piles. This effect is apparent when it is directly on the pile group, at a high level of stress. In the early loading stages, group and the load separation layer thickness increases, the load separation portion starts to decrease rapidly and is a constant value in the end. 


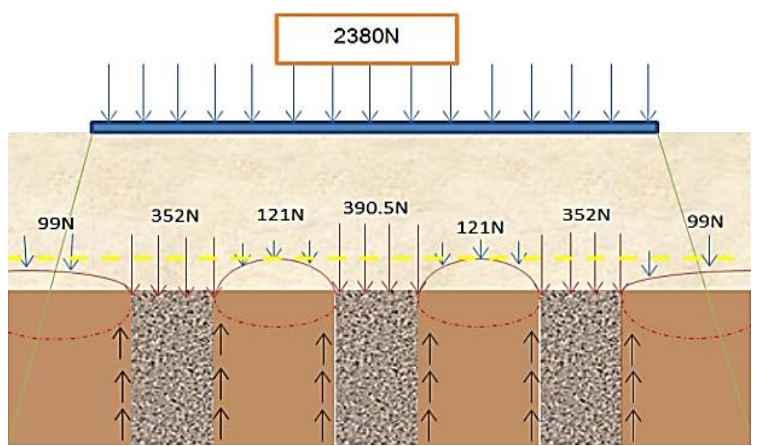

Figure 17. Sharing load of disconnected piled raft using Geogrid on pile directly under cushion of thickness 1.0B.

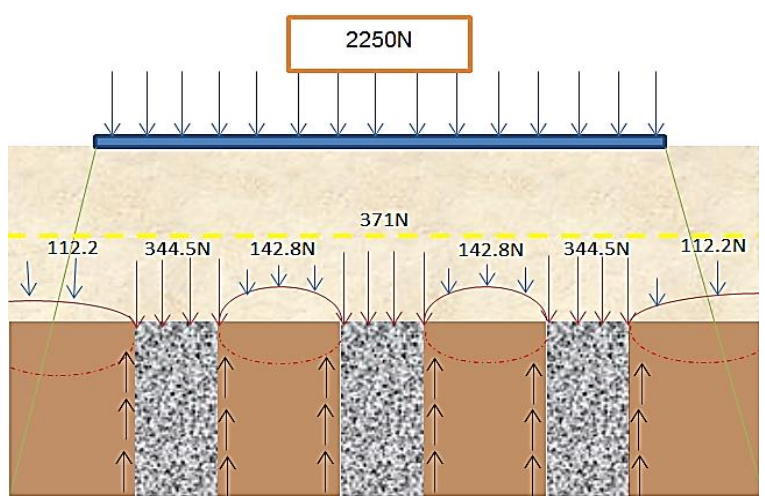

Figure 19. Sharing a load of disconnected piled raft using Geogrid at a depth of cushion thickness of $0.5 \mathrm{~B}$ on the pile group.

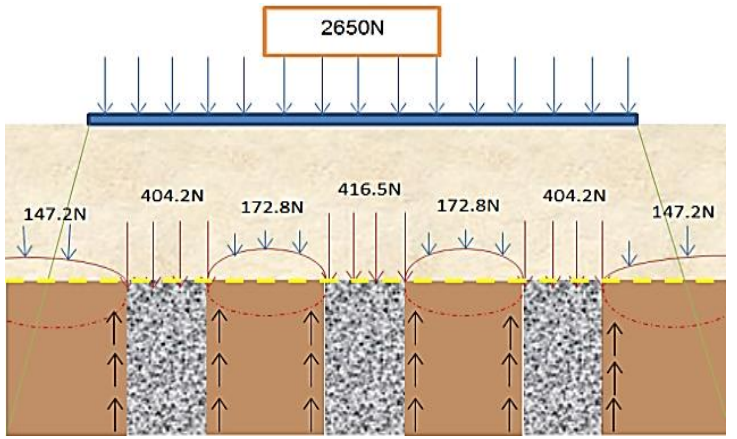

Figure 18. Sharing load of disconnected piled raft using Geogrid at depth of cushion thickness $0.75 \mathrm{~B}$ on pile group.

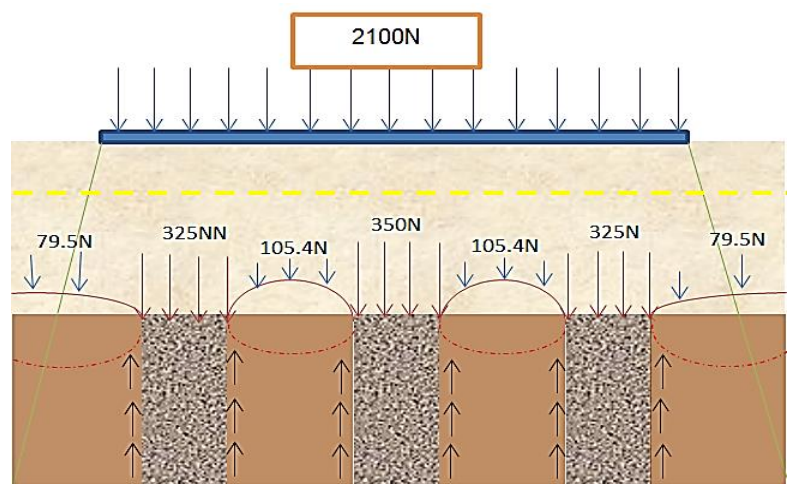

Figure 20. Sharing a load of disconnected piled raft using Geogrid at a depth of cushion thickness of $0.25 \mathrm{~B}$ on the pile group.

Effect of adding Geocell layer. The recently designed technology geocell reinforcement is a threedimensional, polymeric structure, the honeycomb structure of joint-linked cells. By the full containment of soil in its pocks, the geocells' reinforcing mechanism can prevent the lateral spread of soil. Therefore, the geocell layer forms a better composite material and acts as a more rigid mate that redistributes the footing load over a larger region. In contrast, the planar reinforcement layers in the cushion allow the vertical loads to be distributed horizontally, thereby minimizing the transfer of the load to the first layer of the geogrid. Figure 21 compares geocell reinforcing foundation bed performance to the reinforced geogrid layer in terms of load settlement behaviors with planar reinforcement layers. From the values of ultimate bearing capacity of geocell reinforcement in Table 7 it's showed that higher stiffness in the geocell reinforced bed system (i.e., a more significant slope of the pressure response curve) and a larger carrying capacity compared to a planar reinforced also greater transmission of loads to the pile and soil Figures 22 to 24.

Table 7. Ultimate bearing capacity for a disconnected piled raft with using geogrid in different locations.

\begin{tabular}{|c|c|}
\hline The case & Qult $(\mathbf{N})$ \\
\hline Clay+ 3piles + Cushion 1B+geogrid one layer & 2650 \\
\hline Clay+ 3piles + Cushion 1B+geogrid two layer & 2800 \\
\hline Clay+ 3piles + Cushion 1B +geogrid three layer & 2900 \\
\hline Clay+ 3piles + Cushion 1B+geocell layer & 3100 \\
\hline
\end{tabular}




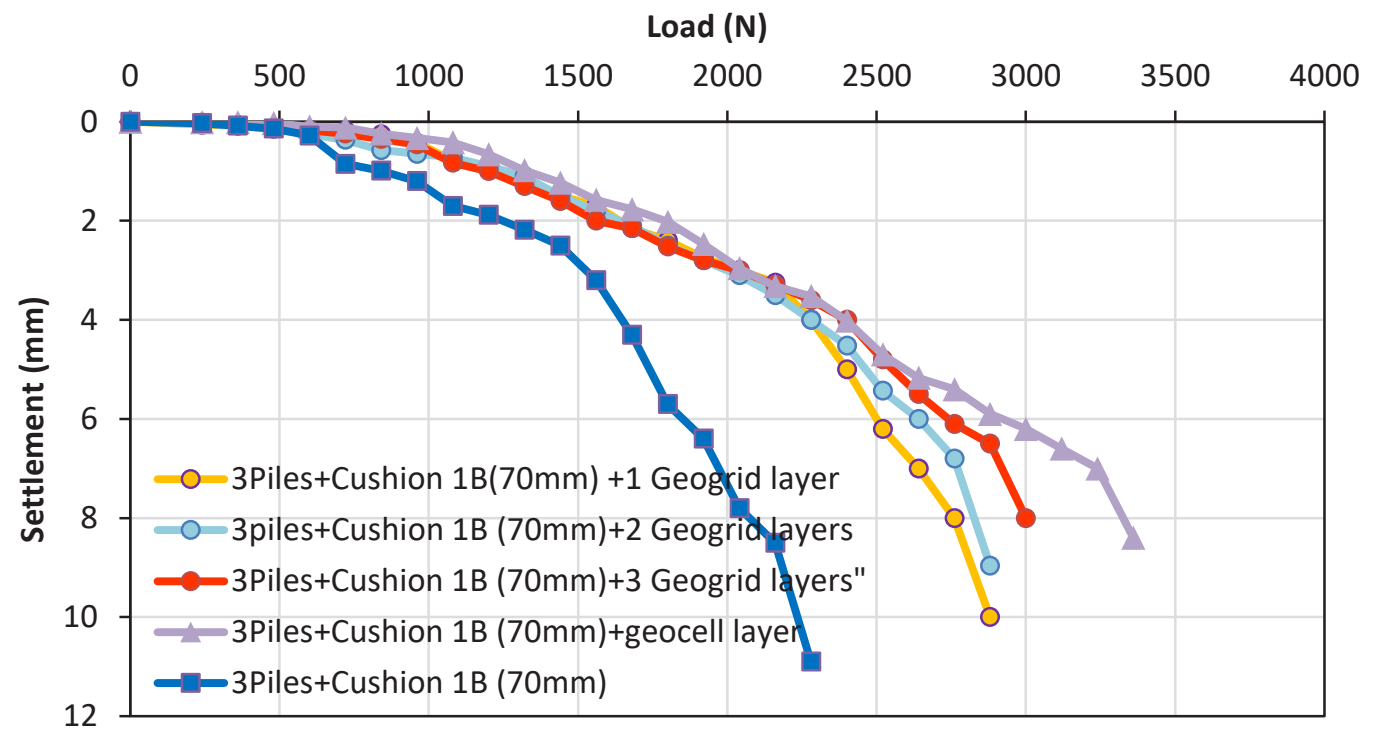

Figure 21. Effect of geocell reinforcement with that reinforced layers of geogrid reinforcement layers in terms of load settlement behavior.

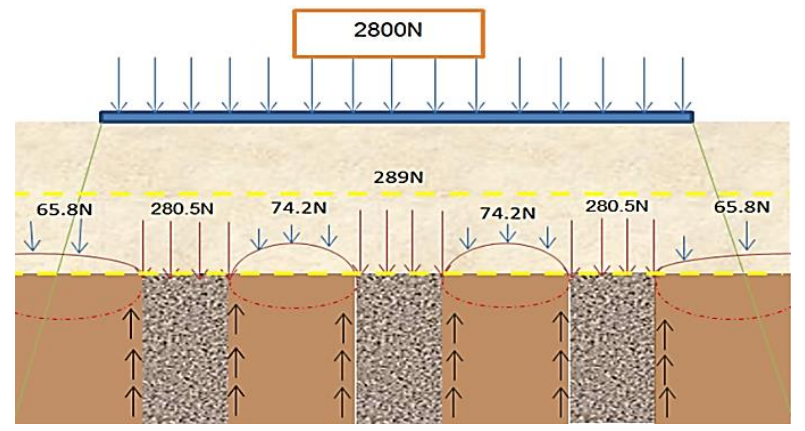

Figure 22. Sharing the load of disconnected piled raft using two geogrid layers thickness $1.0 \mathrm{~B}$.

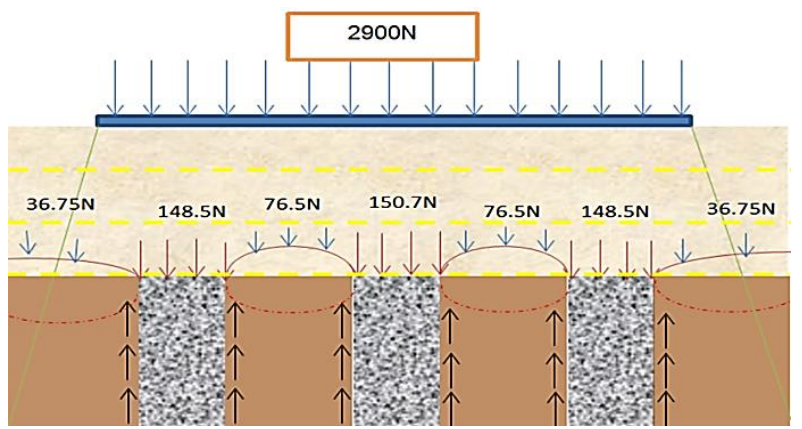

Figure 23. Sharing the load of disconnected piled raft using three geogrid layers thickness

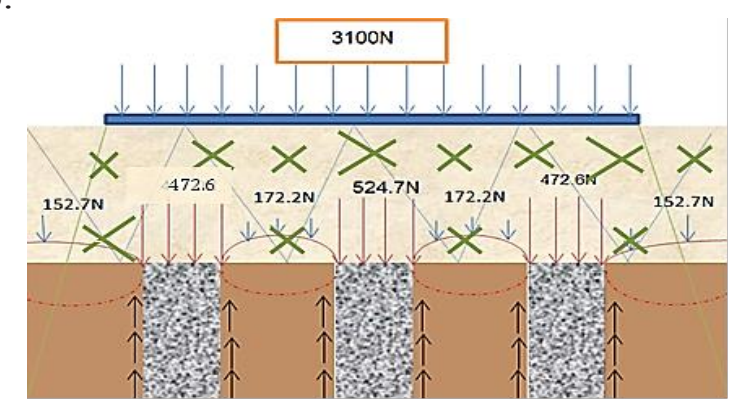

1.0B.

Figure 24. Sharing the load of disconnected piled raft using two geogrid layers thickness 1.0B.

\section{Conclusions}

Based on the experimental results, the following conclusions can be reached:

1. In the case of a relatively thin layer of cushion $(\mathrm{H}<\mathrm{B})$, the bearing pressure was extended to the subgrade (soft clay) which has low resistance. As with the thick layer $(\mathrm{H}=\mathrm{B})$, the failure surface develops inside the cushion layer, and the reactions of the layer are dominated by the cushion behavior.

2. The increase in the thickness of the cushion results in the reduction of the portion of the piles from the total load applied, and a large quantity of the load on a cushion is exhausted, which allows very little force to be applied to the pile. 
3. Sharing the load between the piles and the soil at the early stages of loading made the portion load of the piles from the total load applied small and, with an increase in the loading rate, the portion of the piles begins to increase steadily and at last, seems to be constant.

4. When the cushion is reinforced with geogrid, an increase in the geogrid's depth above the head of the piles leads to a reduction in the bearing capacity. In case of geogrid directly on the pile $(\mathrm{H}=\mathrm{B})$. The force applied to the pile rises and, as a result, the bearing pressure also increased.

5. Increased geogrid layers affect maximum settlement and also low load transfer to the pile group and soil

6. The geocell layer's use to improve the cushion layer significantly increases the load-bearing capacity, reduces the footing settlement, and increases the axial load on piles and soil.

\section{References}

[1] Burland, J.B., Broms, B.B. and De Mello, V.F., 1978. Behaviour of foundations and structures. International Conference on Soil Mechanics and Foundation Engineering, Tokyo, Japan.

[2] Wong, I.H., Chang, M.F. and Cao, X.D., 2000. Raft foundations with disconnected settlementreducing piles. In Design applications of raft foundations (pp. 469-486). Thomas Telford Publishing.

[3] Cao, X.D., Wong, I.H. and Chang, M.F., 2004. Behavior of model rafts resting on pile-reinforced sand. Journal of Geotechnical and Geoenvironmental engineering, 130(2), pp.129-138.

[4] Liang, F., Li, J. and Chen, L., 2006. Optimization of composite piled raft foundation with varied rigidity of cushion. In Foundation analysis and design: innovative methods (pp. 29-34).

[5] Fioravante, V., 2011. Load transfer from a raft to a pile with an interposed layer. Géotechnique, 61(2), pp.121-132.

[6] Eslami, A. and Malekshah, S.S., 2011. Analysis of non-connected piled raft foundations (NCPRF) with cushion by finite element method. Computational Methods in Civil Engineering, 2(2).

[7] Sharma, V.J., Vasanvala, S.A. and Solanki, C.H., 2012. Effect of cushion on composite piled raft foundation in layered soil under seismic forces. International Journal of Scientific Engineering and Technology, 1(6), pp.314-322.

[8] ASTM D 4318-93, 1994. Standard test method for liquid limit, plastic limit and plasticity index of soils. American Society of Testing Materials, USA.

[9] ASTM Committee D-18 on Soil and Rock, 2010. Standard test methods for specific gravity of soil solids by water pycnometer. ASTM international.

[10]ASTM Committee D-18 on Soil and Rock, 2007. Standard Test Methods for Laboratory Compaction Characteristics of Soil Using Standard Effort (12 $400 \mathrm{Ft}-\mathrm{lbf} / \mathrm{ft} 3(600 \mathrm{KN}-\mathrm{m} / \mathrm{m} 3)) 1$. ASTM international.

[11] ASTM, D., 2000. 4253. Standard Test Methods for Maximum Index Density and Unit Weight of Soils Using a Vibratory Table. ASTM International.

[12] EX, L. and INNO, N., International Journal of Engineering and Advanced Technology...

[13] Gade, V.K., Dasaka, S.M. and Chauhan, V.B., 2014. Calibration of tactile pressure sensor. In Proceedings of Indian geotechnical conference, Kakinada, India (pp. 272-279).

[14]Bush, D.I., Jenner, C.G. and Bassett, R.H., 1990. The design and construction of geocell foundation mattresses supporting embankments over soft grounds. Geotextiles and Geomembranes, 9(1), pp.83-98.

[15] Dash, S.K., Krishnaswamy, N.R. and Rajagopal, K., 2001. Bearing capacity of strip footings supported on geocell-reinforced sand. Geotextiles and Geomembranes, 19(4), pp.235-256.

[16]ASTM, D., 2003. 1194-94: Standard Test Method for Bearing Capacity of Soil for Static Load and Spread Footings. ASTM International, West Conshohocken.

[17] Fellenius, B., 2017. Basics of foundation design. Lulu.com. 